\title{
KEMAL PAŞAZADE TARAFINDAN TERCÜME EDİLDİĞi DÜŞÜNÜLEN BİR RİSALE: AHVÂL-İ KIYÂMET
}

\author{
Doç. Dr. Özer ŞENÖDEYİCI*
}

ÖZ: Kutsal kitapların, mutlaka gerçekleşeceğini bildirdiği k1yamet hakkında, farklı inançların farklı yaklaşımları bulunmaktadır. İslâm coğrafyasında "gaybı ancak Allah'ın bildiği"ni ifade eden ayete rağmen, zaman zaman bir kıyametin yaklaşmakta olduğunu iddia ederek birtakım çıkarlar sağlamak isteyenler zuhur etmiştir. Kâinatın son demlerinde gerçekleşecek olan ve kutsal kitaplarda bahsedilen dehşetli hadiselerin verdiği korku, insanların yakın zamanda gerçekleşeceği öngörülen kıyamet senaryolarına rağbet etmeleri sonucunu doğurmuştur. XVI. yüzyılın hemen başında, böyle bir korkuyu teskin etmek için yazılan Celâleddîn Suyûtî̀ye ait Kitâbü'l-Keş̧f 'an Mücâvezeti Hâzihi'l-Ümmeti el-Elf adlı Arapça eser, aynı tedirginliği yaşayan Anadolu Türklüğünün de dehşete kapılmaması için Türkçeye tercüme edilmiştir. Bu tercümelerin serlevhalarında eserin Ebussu'ûd Efendi, Kemal Paşazade, Gelibolulu Mehmed ve Gelibolulu Mahmud gibi isimlere izafe edildiği dikkati çekmektedir. Çalışmada, ilgili tercümenin on bir nüshadan tenkitli metni hazırlanmış ve eserin Kemal Paşazade'ye ait olması muhtemel bir tercüme olduğu dile getirilmiştir.

Bu risalede müellif, hadislere göre dünyanın yedi bin yıl yaşayacağını dile getirmiş, bazı hesaplamalar yaparak kıyametin kopmasına birkaç asır daha bulunduğunu ortaya koymuştur. Daha önce bu hususta yapılan bazı yorumları, kendi süzgecinden geçiren müellif, büyük alâmetlerin gerçekleşeceği zaman dilimi içine girilmediği sonucuna ulaşır. Eser, Kemal Paşazade tarafından secili olarak tercüme edilmiştir. Bu durum, onun meadla (bitiş, Kıyamet) ilgili edebî bir eser olarak değerlendirilmesini zorunlu kılmaktadır.

\footnotetext{
* KTÜ Edebiyat Fak. Türk Dili ve Edebiyatı Böl., ozersenodeyici@ gmail.com
} 
Anahtar kelimeler: Kıyamet, hadis, Celâleddîn Suyûtî, mebde ve mead, Kemal Paşazade

\section{A Traeatise About the Doomsday Believed to be Translated Translated by Kemal Paşazade: Ahvâl-i Kıyâmet}

ABSTRACT: There are many different approaches of different faiths about the Doomsday which holy books reported that it would occur in one day. In Islamic lands despite a holy Quranic verse that says "Only God knows unseen facts" sometimes those who want to provide some interests has arrived by claiming an impending doom. The fear of horrendous events which will take place in the last moments of universe and mentioned in the holy books have resulted to demand people to scenarios of a recently doomsday. Celâleddin Suyûtî's book named Kitâbü'l-Keşf 'an Mücâvezeti Hâzihi'l-Ümmeti el-Elf which is written by Arabic at the begining of XVIth century to placate such fear was translated not to be terrified of Anatolian Turks who became upset. In the titles of these translations we see different names such Ebussu'ûd Efendi, Kemal Paşazade, Gelibolulu Mehmed and Gelibolulu Mahmud as its translator. In this study a copy with critic of this text has been prepared and it claims that this translation had been translated done by Kemal Paşazade.

In this treatise author says that world's life would be seven thousand years and claims that there would be a couple of centuries for doomsday by some calculations. The author critisized some comments made earlier in this regard and conludes that the great omens of doomsday have not emergenced yet. This tratise is translated rhymed -accoordance with original- by Kemal Paşazade. This situation is mandates to evaluate the treatise as a literary work about genesis and doomsday.

Key Words: Doomsday, hadith, Celâleddîn Suyûtî, genesis and armageddon, Kemal Paşazade

\section{GíRiş}

Pek çok dinî inanç, dünyadaki insan varlığının büyük bir felâketle son bulacağını öngörür. İman edenlerin diğerlerinden ayırt edileceği ve sonsuz bir yaşamın başlayacağı bu felaket, İslâm dininde $\mathrm{kl}$ yamet sözcügü ile ifade edilmiştir. Diyanet Vakfi İslâm Ansiklopedisi'nde bu hadisenin kozmik sistemde meydana gelecek değişimle başlayacağı ifade edilmiştir. ${ }^{1}$ Sosyal, kültürel, teknolojik değişmelere pa-

1 "Kıyamet: Dünyanın bağlı olduğu kozmik sistemde meydana gelecek değişimin ardından ölülerin diriltilmesiyle başlayıp ebediyen devam edecek olan âlem." 
ralel olarak çeşitli zamanlarda insanlığın mutlak sonu hakkında farklı yorumlar yapılmıştır. Son asırda ise, kozmik âlemde gerçekleşecek hadiselerin dünyadaki yaşama olanak sağlayan hassas dengeyi bozacağı ve böylece hayatı sonlandıracağı üzerinde durulmaktadır.

Kıyamet telakkisi farklı din ve inanışlarda farklı anlayışların doğmasına sebep olduğu gibi kimi inanışların temel argümanını teşkil etmiştir. İslâm coğrafyasında da kıyametin zamanı ile ilgili çeşitli spekülasyonlar yapılagelmiştir. Kur'ân'da Hazreti Muhammet'e kıyametin zamanı ile ilgili olarak yöneltilen sorulara açık bir şekilde cevap verilmiş, Peygamber de dâhil hiçbir insana bu bilginin verilmediği vurgulanmıştır:

"Sana, kıyamet saatinin ne zaman gelip çatacă̆ını soruyorlar, de ki: «Onu ancak Rabbim bilir, onun vaktini, O'ndan başka belirtecek yoktur. Göklerin ve yerin, ă̆ırlığını kaldıramayacă̆ı o saat, sizlere ansızın gelecektir.» Sen sanki öğrenmişsin gibi sana soruyorlar, de ki: "Onu bilmek ancak Allah'a mahsustur, ama insanların çoğu bu gerçeği bilmezler.» " (A'raf / 187).

Bununla birlikte Kur'an'da, gerçekleşecek büyük felaketin yaklaştığına işaret eden çeşitli alametlerin bulunduğu bildirilmiştir. Yecüc ve Mecuc'un gelişi (Enbiya / 96), dâbbetü'l-arzın çıkışı, (Neml / 82), göğün insanları saracak bir duman (duhan) yayacağı (Duhan/11-12), göğün yarılması (İnşikak/1-2), göğün dürülmesi (Enbiya/104), dağların yürütülmesi (Kehf/47. Tekvir/3), denizlerin kaynaştırılması (Tekvir/6), güneşle ayın birleştirilmesi (Kıyame/10) ve ayın yarılması (Kamer/1) Kur'an'da anılan alametlerdir (Malkoç 2010: 28).

Bazı hadislerde de kıyametin yaklaştığını haber veren kimi işaretlere temas edilmiştir. Temel İslâmî kaynaklarda bahsedilen alametlerden bazılarını şöyle sıralayabiliriz: Fitnenin, insanların ölümü isteyecek kadar çoğalması, insanları doğudan batıya sürecek bir ateşin çıkması, Kahtan'dan insanları asasıyla sürecek bir adamın çıkması, aynı davaya sahip iki Müslüman grubun birbiri ile savaşması, Müslümanlar arasında malın çoğalması, cariyenin efendisini doğurması, ilmin azalması ve cehaletin artması, kötülerin yönetimi ele geçirmesi, Fırat nehrinin çekilerek nehir yatağından altın çıkması, depremlerin çoğalması, kadınların çoğalıp erkeklerin azalması (Altuntaş 2007: 2122).

(Topaloğlu 2002: 516). 
İslâm dünyasında, Hazreti Peygamber'e izafe edilen bazı rivayetlerden hareketle kıyamet beklentisine bağlı bir milenyum (binyılc1l1k) telakkisi doğmuştur. Bu inancın temeli Hazreti Muhammet'in "Peygamber, kabrinde bin yll durmaz" mealindeki bir sözüne istinat etmektedir. Doğruluğu muteber kaynaklarca teyit edilmeyen bu rivayet, Peygamber'in ölümünden bin y1l sonra (M.1591) kıyamet kopacağına yorulmuştur (Baş 2005: 171-172).

XVI. yüzyılda böyle bir beklentinin oluşması, bu hususa yönelik bazı açıklamaların yapılmasını zaruri hale getirmiş, insanlar âlimlerden kıyamet hususunda açıklamalar beklemiştir. Bu çalışmaya konu olan Celâleddin Suyûtî'ye ait eser ve onun tercümesi de bu ihtiyaca cevap vermek için yazılmıştır.

\section{Kemal Paşazade ve Ahvâl-i Kıyâmet}

Kemal Paşazade'nin hayatı hakkındaki bilgilerde kimi ihtilaflar bulunsa da, hakkında söz sarf eden bütün kaynaklar onun ilminden ve irfanından övgüyle bahsetmişlerdir. Şeyhülislâm unvanının yanı sıra Müfti'l-Enâm, Müfti's-Sakaleyn, İbn Sînâ-y1 Rûm gibi lakaplarla da anılan Kemal Paşazade, 1468 yılında dünyaya gelmiştir.

Asıl adı Şemseddin Ahmed Çelebi'dir. Sultan I. Selim döneminde yıldızı parladıktan sonra önce Edirne kadısı olmuş, 1516 yılında da Anadolu kazaskeri tayin edilmiştir. Çeşitli medreselerde müderrislik yapan Kemal Paşazade, 1526 yılında şeyhülislâmlık makamına getirildi (Saraç, 1999: 13-19).

Osmanlı bürokrasisinde önemli bir yer tutan, ilmî kudretiyle dikkatleri çeken Kemal Paşazade'nin azımsanmayacak sayıda edebî eseri de vardır. Sehî Bey, onun gazellerinin yanı sıra Yûsuf u Züleyhâ mesnevisini, Tevârîh-i Âl-i Osmân adlı tarihini ve Nigâristân adlı Farsça eserini övgüyle anar (İsen, 1998: 97)

Kemal Paşazade, hem ilmî hem de edebî kimliği ile takdir topladığ1 gibi şahsiyetiyle de olgunluk göstermiş³; böylece başta Sultan

2 Aynı çalışmada XVI. yüzyıl Osmanlı coğrafyasında Kâtip Çelebi, Gelibolulu Mustafa Âlî, Selânikî Mustafa Efendi, Kadızade Ahmed Şemseddin gibi âlim ve müelliflerin kıyamet beklentisi içinde olduklarına değinilmiştir (Baş 2005: 17216).

3 Gelibolulu Âlî, Künhü'l-Ahbâr adlı eserinin şairlerden bahseden bölümünde Ârifî adlı bir şairin Kemalpaşazade'yi eleştiren bir şiiri kendisine sunduğunu, karşıllğında ise takdir gördüğünü şöyle anlatır (1994: 242): 
Selim olmak üzere devrin önde gelen isimlerinin hürmetini kazanmıştır. Hatta Sultan Selim ile aralarında geçen bir diyalog Osmanlıların ulemaya duyduğu saygının timsali olmuştur. ${ }^{4}$

Devrinin etkin şahsiyetlerinden biri olan Kemal Paşazade, 1534 tarihinde vefat ettiği zaman ardında pek çok eser bırakmıştır. Tespit edilebilen Türkçe telif eserleri şunlardır: Divan, Yûsuf u Züleyhâ, Kafiye Risalesi, Nasâyı h, Usul-nâme, Bürde ve Tantarâniyye Kasidelerinin Manzum Tercümeleri, Dakâyıku'l-Hakâyı, Câmi' 'ü'l-Fürs, Türkçe Fetvalar, Rücû'u'ş-Şeyh ilâ Sibâhi fi'l-Kuvveti 'ale'l-Bâh Tercümesi (Saraç, 1999: 42-43). Müellifin, bunların yanı sıra sayısı üç yüzü aşan risalelerinin bulunduğu rivayet edilmektedir. Bu risalelerinin otuz altı tanesi Ahmed Cevdet tarafından İkdâm neşriyatı arasından yayımlanmıştır (Parmaksızoğlu, 564). Çalışmaya konu olan risalenin de onun çok sayıdaki telifatından biri kabul edilmesi gerekmektedir.

\section{Eser Bilgileri}

Ahvâl-i Kıyâmet'in on bir nüshası tespit edilebilmiştir. Söz konusu nüshaların bulunduğu kütüphaneler ve rumuzları aşağıdaki tabloda gösterilmiştir:

\begin{tabular}{|l|l|l|l|}
\hline Nüsha & Nerede Yer Aldığı & Arşiv Numarası & Kime Atfedildiği \\
\hline A & İstanbul Millet K. & 34 Ae Manzum 573/2 & Kemal Paşazade \\
\hline B & $\begin{array}{l}\text { Kayseri Raşit Ef. } \\
\text { K. }\end{array}$ & Raşid Efendi 196/9 & Ebussu ûd Efendi \\
\hline C & Ankara M.K. & 06 Mil Yz A 5401/2 & Celâleddîn Suyûtî \\
\hline D & Ankara M.K. & 06 Mil Yz A 5693/7 & $\begin{array}{l}\text { Kemal Paşazade } \\
\text { (sonda) }\end{array}$ \\
\hline
\end{tabular}

“Ve bu kıt'a dahi anuñdur. Kemâlpaşazâde merhûma virmişdür. Kemâl-i nezâket-i tab'ından incinmeyüp tahsîn-i belîğ buyurmışdur:

İmâm-1 dîn ü millet ya'nî müftî

Ki yokdur aña beñzer ehl-i âdem

Şu deñlü ihtisâr eyler cevâbın

Olur olmaz yazar vallâhu a'lem"

4 Buna göre Mısır Seferi esnasında Kemalpaşazade'nin atının ayağından sıçrayan çamur, Sultan Selim'in kaftanına bulaşır. Bunun üzerine Selim, ulema ayağından sıçrayan çamurların medâr-1 zînet ve mefharet olacağını söylemiş ve o kaftanın, ölümünden sonra sandukası üzerine örtülmesini vasiyet etmiştir (Saraç, 1999: 32). 
TÜBAR-XXXVI-/2014-Güz / Özer ŞENÖDEYİCİ

\begin{tabular}{|l|l|l|l|}
\hline E & İstanbul Millet K. & 34 Ae Şeriyye 905/3 & $\begin{array}{l}\text { Kemal Paşazade } \\
\text { (sonda) }\end{array}$ \\
\hline F & Ankara M.K. & 06 Hk 4328/1 & Celâleddîn \\
\hline G & Ankara M.K. & 06 Mil Yz A 1941/2 & $\begin{array}{l}\text { Gelibolulu Mehmed } \\
\text { Çelebi }\end{array}$ \\
\hline H & $\begin{array}{l}\text { Çorum Hasan Paşa } \\
\text { K. }\end{array}$ & 19 Hk 798/1 & $\begin{array}{l}\text { Gelibolulu Mahmûd } \\
\text { Çelebi }\end{array}$ \\
\hline I & $\begin{array}{l}\text { Konya Bölge } \\
\text { Yazma Eserler K. }\end{array}$ & 32 Yalvaç 107/12 & Mevlânâ Celâleddîn \\
\hline İ & Manisa İl Halk K. & 45 Hk 1660/2 & $\begin{array}{l}\text { Kemal Paşazade } \\
\text { (sonda) }\end{array}$ \\
\hline J & $\begin{array}{l}\text { Kastamonu Yazma } \\
\text { Eser K. }\end{array}$ & 37 Hk 1073/9 & $\begin{array}{l}\text { Kemal Paşazade } \\
\text { (sonda) }\end{array}$ \\
\hline
\end{tabular}

Temin edilen on bir nüshanın her biri birbirinden farklı başlıklar taşımakta ve bu başlıklarda eserin müellifi olarak farklı şahıslar anılmaktadır. Ancak eldeki karinelerden hareketle bu başlıkların nasıl konulmuş olabileceğine dair bazı sonuçlara ulaşılabilmektedir. Eserin as11 Celâleddîn Suyûtî'nin Kitabü'l-Keşf 'an Mücâvezeti Hâzihi'l- Ümmeti el-Elf $f^{5}$ adlı risalesinin tercümesidir. Ancak eser Osmanlı süslü nesrine adapte edilmek için aslından mealen olmasa da lafzen uzaklaşmıştır. Eserin sahibinin Celâleddîn Suyûtî olduğu C, F, G, H ve I nüshalarında başlıkta belirtilmiştir. Bu başlıkların haricinde eserin A ve $E$ nüshalarındaki serlevha onun İbn Kemal'e ait olduğuna işaret ederken B nüshası Ebussuûd Efendi'ye ait olduğunu iddia etmektedir. G nüshası eseri Gelibolulu Mehmed Çelebi'nin tercüme ettiğini söylerken H nüshası bu ismi Gelibolulu Mahmûd Çelebi olarak aktarır. F nüshasının başlığında yalnızca Celâleddîn, I nüshasında ise Mevlânâ Celâleddîn ismi anılırken $\mathrm{E}$ nüshasının hem başında hem de ferağ kaydında eserin İbn Kemal'e ait olduğu belirtilir. Başlıksız olan D, İ ve J nüshalarının sonunda da eserin İbn Kemal'e ait olduğu yinelenmiştir. Bu veriler Celâleddîn Suyûtî'ye ait bir telifin Kemal Paşazade tarafından tercüme edilmiş olabileceğine işaret etmektedir. ${ }^{6}$ Tüm nüs-

5 Eserin orijinal metni için bk.

http://library.islamweb.net/newlibrary/display_book.php?idfrom $=465 \&$ idto $=469 \&$ bk_no=130\&ID=22 (e.t. 30/01/2014).

6 İbn Kemal ile Celâleddin Süyûtî'nin çeşitli kaynaklar tarafından mukayese edildiğine dikkat çekmek gerekir. Sözgelimi Ömer Nasuhi Bilmen, Büyük Tefsir Tarihi adlı eserinde Abdülhây el-Lûknevî’nin bu türden bir kıyaslamasına yer 
halarda Celâleddîn Suyûtî adı bir şekilde anılmaktadır. Değerlendirmeye alınan on bir nüshanın iki tanesinde başlıkta, üç tanesinde de sonda Kemal Paşazade adı anılmaktadır. Bu durumda beş nüshanın delaletiyle çevirinin İbn Kemal tarafından yapıldığı söylenebilir. Ancak Ebussuûd Efendi, Gelibolulu Mehmed ve Gelibolulu Mahmud adlarının da birer ihtimal olarak anılması gerekir.

Tarihin her döneminde çeşitli kehanetler söyleyen, kendi düşüncesini yakın bir zamanda gerçekleşecek bir kıyamete yaslayan ve insanları bu suretle dehşete düşürerek kendine bağlamaya çalışan birçok sahte peygamber, mehdi ve Mesih zuhur etmiştir. Suyûtî kendi döneminde bu türden sahtekâr kimselerin insanlara kıyamet korkusu aşılayıp onları kandırmasına kayıtsız kalamadığı için eserini yazmış olmalıdır. Osmanlı şeyhülislâmı İbn Kemal'in de Osmanlı tebaasının bu konudaki merakını gidermek için ilgili eseri Türkçeye aktardığı düşünülebilir.

Eserde dünyanın ömrünün yedi bin yıl olduğunu dile getiren bir hadis değerlendirilir. Hz. Peygamberin bir başka hadisinde kendisinden sonra ümmetinin sadece bin yıl daha yaşayacağı dile getirilmektedir. Eserin müellifi halk arasında yaygın olan bu düşünceye karşı çıkmaktadır. Ona göre bin yılın dolmasına 102 sene kalmıştır. Hâlbuki kıyametin kopacağını işaret eden kesin deliller mahşerden iki yüz sene önce gerçekleşmeye başlayacaktır. ${ }^{7}$ Yani Deccal'ın inişi İsa Peygamberin onu öldürüşü ve dünyada kırk sene yaşaması daha sonra güneşin

verir (Bilmen, 1973: 636-637): “Reddü'l-Muhtâr'da Tabakâtü’l-Temîmî’den naklen deniliyor ki: 'Âllâme Ahmed bin Süleyman [İbn Kemal] her ilimde yed-i tûlâ sahibi idi. Hiçbir fen yoktur ki ona dair bir veya müteaddit kitabı bulunmasın. Telifâtının kesreti, ittilaının vüs'ati itibarıyla Celâleddîn-i Süyûtî gibidir; diyâr-ı Misriyye'de Süyûtî ne ise, diyâr-1 Rûm'da da İbn Kemâl odur. Bence İbn Kemâl, Süyûtî' den daha ziyade dikkat-i nazara, hüsn-i fehme mâliktir. Her ikisi de asrının ziyneti idi.' Fakat ben derim ki: İbn Kemâl her ne kadar edebiyata usûle ittilâ‘ cihetiyle Süyûtî' ye müsâvî olsa da hadis ilimlerinde ona müsâvî olamaz. Süyûtî bu ilimler bakımından daha vâsi “ bir nazara, daha ince bir fikre mâlikti. Zannımca Süyûtî’den sonra kendisinin bir misli daha gelmemiştir. İbn Kemâl ise hadis ilminde bezâası azdır."

7 Kur'ân'da kıyametin kopacağı zamanı Allah'tan başkasının bilemeyeceği bildirilir. Ayrıca bazı ayetlerde kıyametin ansızın kopacağı da bildirilir. Süyûtî her ne kadar, büyük alametlerin gerçekleşmediğini öne sürerek kıyametin daha ileri bir tarihte kopacağını belirtse de, kıyameti her an gerçekleşebilecek bir olay olarak gören ikinci bir yaklaşım daha bulunmaktadır. Buna göre insan, her an kıyamet kopabileceğini düşünerek yaşarsa, daha sorumlu ve daha olumlu bir hayat sürer. Bu yaklaşımla ilgili olarak bkz. (Kalkan 2012: 25-33). 
batıdan doğması ve bundan sonra insanlığın 120 yıl daha yaşaması hesaba katıldığında ortaya 200 rakamı çıkmaktadır. 1000 senenin dolmasina 102 sene kalıp son 200 senede görülmesi gereken hadiselerin gerçekleşmemesi, bu inanışın ve isnat edilen hadisin hatalı olduğunu gösterir. Verilen bu bilgi eserin yazıldığı tarihi de ortaya çıkarmaktadır. Anlaşıldığı kadarıyla Suyûtî, Hz. Peygamber'in vefatının bininci senesinin dolmasına 102 sene kala risalesini yazmıştır. Basit bir hesaplamaya gidildiğinde eserin H. 909 / M. 1503 yılında telif edildiği ortaya çıkar.

\section{Eserin Muhtevası}

Celâleddîn Suyûtî'ye ait Kitâbü'l-Keşf 'an-Mücâvezeti Hâzihi'lÜmmeti el-Elf adlı eserin tercümesi mahiyetindeki Ahvâl-i Kıyâmet, eserin orijinali gibi secili bir üslupla yazılmıştır. Bu nedenle edebi bir mahiyet de taşıyan risalenin secilerinden bazı örnekler vermek gerekir:

Hamd-i bī-nihāye ve senā-yı bī-gāye ol Hālık-1 semāvāt-1 bedíc ü'n-nizāma ve Șāni' -i neyyirāt-1 'acỉbü'l-intizāma lāyıḳdur

necm-i burc-1 hidāyet ve seyyāre-i nüh çarhn-1 'ināyet

\section{bu hadd ile mahdūd ve bu 'add ile ma'düd}

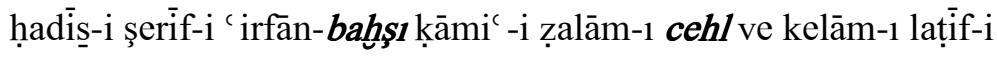
ma' ārif-naḳssı lāmi' -i envār-1 'aḳl u naḳl

Eserin tertibinde eski metinlerin ekserisinde görülen hiyerarşi takip edilmiştir. Eserin adı ve "besmele" kimi nüshalarda tercihen farklı şekillerde yazılmış ya da hiç yazılmamış olsa da muhtevanın ilk cümleleri hamd ü senaya tahsis edilmiştir. Daha sonra Hz. Peygamber'e, onun ailesine, ashabına, evladına ve ahbabına salât ve selam gönderilmiştir. Ardından eserin müellifi Celâleddîn Suyûtî oldukça sitayişli sözlerle övülerek onun tespitlerine yer verilmiştir. Buraya kadarki kısım oldukça ağır bir üsluba sahiptir.

Halk arasında Hz. Peygamber'in kabr-i pâkinde 1000 yıldan fazla kalmayacağına, bu sürenin sonunda kıyamet kopacağına dair inancın asılsız olduğu dile getirilir. Daha sonra Tirmizî'nin Nevâdirü'l-Usûl' ünde yer verdiği bir hadisin açıklamasına yer verilir. Eserin ortaya koymaya çalıştığı tez şu şekilde özetlenebilir: 
Hz. Âdem'in yaratılışından kıyametin kopmasına kadar geçen süre 7000 yıldır. Hz. Peygamber, altıncı bin yılın sonunda gönderilmiştir. Hatta bir hadisinde dünyanın yaratılışından 5600 sene sonra dünyaya geldiğini söylemiştir. Öyleyse 7000 y1lı tamamlamak için 1000 yılın üzerine 400 yıl daha ilave etmek gerekir. Bu hesaba göre kıyametin kopmasına birkaç asır daha vardır. Eserin yazılış nedeni bu hesaplamalarda kendisini açık bir şekilde hissettirmektedir. Kıyametin yakın bir zamanda kopacağına dair yaşanan korkuyu teskin etmek için müellif bu kaçınılmaz sonu birkaç asır daha ertelemiştir.

Yakın bir zamanda kıyametin kopacağına dair söylentiler yayılması insanların alışılmışın dışında hareket etmeleri sonucunu doğurur. Bütün kutsal kitapların heybetinden ve dehşetinden bahsettiği k1yamet günü geldiğinde ölüler topraktan kalkacak ve hesaba çekileceklerdir. Bu zamanın oldukça yakın olduğunu bilen bir kişi dünyada gerçekleştirmesi gereken vazifeleri önemsemez ve korkunun kendisine verdiği şaşkınlıkla yanlış yollara sapabilir.

Bütün bunların yanı sıra insanların çeşitli kıyamet senaryoları üretmeleri yakın bir zamanda gerçekleşecek kıyamete dair bazı söylentilere inanmaları, onların dünya düzenine saygı göstermemeleri sonucunu da doğurur. Bu tehlikeyi sezen İbn Kemal, Suyûtî'nin konu hakkındaki ilgili eserini tercüme etme gereği hissetmiştir. Böylece k1yametin kendi neslinin tanık olacağı kadar yakın bir sürede kopmayacağına dair insanlara telkinlerde bulunmuştur. Esasen Kur'an-1 Kerim'de "Gaybı ancak Allah bilir" ${ }^{\text {"8 }}$ mealindeki ayet bu türden kuruntulara verilebilecek en güzel cevap olmakla birlikte yine de insanlara sayısal bazı delillerle sunulmak yoluyla merakları giderilmeye çalışılmıştır.

\section{Nüsha Tavsifleri ${ }^{9}$}

\section{Risâle-i Ahvâl-i Kıyâmet (A nüshası)}

İstanbul Millet Kütüphanesi Ali Emîrî Koleksiyonunda 34 Ae Manzum 573/2 arşiv numarası ile kayıtlıdır.

$$
\text { عجيب الانتظامه لايقدركه نثايه بى غايه اول خالق سموات بديع النظامه و صانع نيّرات }
$$

\footnotetext{
${ }^{8}$ Kur'an-1 Kerim 27 Neml- 65

${ }^{9}$ Nüsha bilgileri yazmalar.gov.tr adresinden alınmıştır.
} 
sözleriyle başlar. Arap-Talik hatla, Türkçe, 141a-142b sayfaları arasında, 23 satırlı, cetvelleri tezhipli kâğıda yazılmıştır. Zahrı ve kenarları meşin, yüzü ebru kâğıt kaplı, şirazeli bir cilt içerisindedir. Müellif adı olarak İbn Kemal (Kemal Paşazade), Şemsüddin Ahmed b. Süleyman b. Kemal Paşa, 873-940 H. kayıtlıdır. Telif ya da istinsah tarihi belli değildir.

$$
\text { آمين يا ارحم الَّر احمين و الحمد لله ربّ العا لمين }
$$

sözleriyle sona erer.

\section{Ahvâl-i Kıyâmet (B nüshası)}

Kayseri Raşit Efendi Eski Eserler Kütüphanesinde Râşid Efendi 196/9 arşiv numarası ile kayıtlıdır. Ancak www.yazmalar.gov.tr'de 1196/9 olarak kayıtlıdır.

$$
\text { الانتظام حضرتيى حده و ثناى لايعد اول خلالق سموآت بدآيع النّام وصانع نبّر ات عجيب }
$$

sözleriyle başlar. Türkçe, 210x136(145x88) mm. ölçüsünde, 68b-72a sayfaları arasında, 17 satırlı kâğıda yazılmıştır. Müellif adı olarak Ebussu' ûd Muhammed b. Muhammed el-İmâdî (898-982/1493-1574) kayıtlıdır. Telif ya da istinsah tarihi belli değildir.

$$
\text { آمين يا ارحم الَّر احمين و الحمد لله ربّ العا لمين م }
$$

sözleriyle sona erer.

\section{Risâle-i Beyân-ı Ömr-i Dünyâ (C Nüshası)}

Ankara Millî Kütüphane Yazmalar Koleksiyonunda 06 Mil Yz A 5401/2 arşiv numarası ile kayıtlıdır.

$$
\text { الانتظاره لايقدركه نهايه ثناء بلا غايه اول خالق النّموات بديع النظّار و صانع نيّر ات عجيب }
$$

sözleriyle başlar. Nestalik hatla, Türkçe, 200x130(145x62) mm. ölçüsünde, 47b - 50b sayfaları arasında, 19 satırlı kâğıda yazılmıştır. Söz başları kırmızıdır. Sırtı yıpranmış, şemseli, koyu bordo meşin kaplı mukavva bir cilt içerisindedir. Şirazesi dağılmıştır. Telif ya da istinsah tarihi belli değildir. Ancak aynı cilt içerisinde 1281(1864) tarihinde istinsah edilmiş bir eser vardır.

$$
\text { دنياياو عاقبتنا خير اً وقدرلنا فى الخنان سيرا امين يا معين تمت }
$$


sözleriyle sona erer.

\section{Risâle fî-Ahvâli’l-Kıyâme (D nüshası)}

Ankara Millî Kütüphane Yazmalar Koleksiyonunda 06 Mil Yz A 5693/7 arşiv numarası ile kayıtlıdır.

$$
\text { الانتظامه لايقدر كه نهايه و ثناء بى غايه اول خالق سموات بديع نظامه و صانع نير ات عجيب }
$$

sözleriyle başlar. Nestalik hatla, Türkçe, 195x145(145x108) mm. ölçüsünde, 38a - 39b sayfaları arasında, 21 satırlı, suyolu filigranlı kâğıda yazılmıştır. Yapraklar rutubet lekelidir. Sırtı siyah meşin, cilt kapakları yıpranmış desenli kâğıt kaplı, mukavva bir cilt içerisindedir. Müstensih adı olarak Seyyid Mehmed Tokadî kayıtlıdır. 1203(1788) tarihinde istinsah edilmiştir. Aynı cilt içerisinde 1110(1698), 1121(1709), 1165(1751), 1195(1780) tarihlerinde istinsah edilmiş 4 eser daha vardır.

$$
\text { و الحمد لله يا رب العالمين م مولفات كمال باشـاز اده }
$$

sözleriyle sona erer.

\section{Risâle fî-Müddeti Hayâti'd-Dünyâ ve Eşrâti's-Sâ'a (E nüs- hası)}

İstanbul Millet Kütüphanesi Ali Emir Emîrî Koleksiyonunda 34 Ae Şeriyye 905/3 arşiv numarası ile kayıtlıdır.

$$
\text { الانتظامه كمد بى حدو ثناى لا يعد اول خالق سموات بديع النّام و صانع نيرات عجيب }
$$

sözleriyle başlar. Arap Nesih hatla, Türkçe, 210x160(175x112) mm. ölçüsünde, 12a - 14a sayfaları arasında, 17 satırlı kâğıda yazılmıştır. Müellif adı olarak İbn Kemal (Kemal Paşazade), Şemseddin Ahmed b. Süleyman b. Kemal Paşa, 873-940 H. kayıtlıdır. Sırtı meşin, yüzü ebru kâğıt kaplıdır. Telif ya da istinsah tarihi belli değildir. Ancak aynı cilt içerisinde 1184(1770) tarihinde istinsah edilmiş bir eser vardır.

$$
\text { و الحمد لله ربّ العالمين لابن كمال عليه رحمة المتعال }
$$

sözleriyle sona erer.

\section{Risâle fî-Beyâni Ömri'd-Dünyâ (F nüshası)}


Ankara Milli Kütüphane Adnan Ötüken İl Halk Kütüphanesi Koleksiyonunda 06 Hk 4328/1 arşiv numarası ile kayıtlıdır.

$$
\text { الانتظامه لايقدركه نهايه ثناء بلا غايه اول خالق السّموات بديع النظام و صانع نيّر ات عجيب }
$$

sözleriyle başlar. Rika hatla, Türkçe, 192x125(155x75) mm. ölçüsünde, 1 b - 5b sayfaları arasında, 17 satırlı, beyaz cedid kâğıda yazılmıştır. Zencirekli, siyah pandizot kaplı mukavva bir cilt içerisindedir. Müellif adı olarak Celâleddin ismi kayıtlıdır. Telif ya da istinsah tarihi belli değildir.

$$
\text { و الله اعلم بالصّو اب على الاطناب تمت م م م }
$$

sözleriyle sona erer.

\section{Terceme-i Ahvâl-i Kıyâmet (G nüshası)}

Ankara Millî Kütüphane Yazmalar Koleksiyonunda 06 Mil Yz A 1941/2 arşiv numarası ile kayıtlıdır.

$$
\text { الانتظامه لايقدركه نهايه ثناء بلا غايه اول خالق سموات بديع النظام و صانع نيّر ات عجيب }
$$

sözleriyle başlar. Nesih kırması hatla, Türkçe, 213x155(100x102) $\mathrm{mm}$. ölçüsünde, $11 \mathrm{~b}$ - 12b sayfaları arasında, 33 satırlı, birleşik harf filigranlı kâğıda yazılmıştır. Beyaz karton bir kap içerisindedir.

Müellif adı olarak Gelibolulu Mehmed Çelebi kayıtlıdır. Telif ya da istinsah tarihi belli değildir. Ancak aynı cilt içerisinde 1077(1665) ve 1097(1685) tarihlerinde istinsah edilmiş ikişer eser vardır. Celâleddin Suyûtî’nin kıyamet kopması ahvaline dair risalesinin tercümesidir.

$$
\text { دنيانا و عاقبتنا خير ا وقّر لنا فى الجنان سير ا امين يا رب العالمين }
$$

sözleriyle sona erer.

\section{Terceme-i Risâle fî-Ahvâli’l-Kıyâme (H nüshası)}

Çorum Hasan Paşa İl Halk Kütüphanesinde 19 Hk 798/4 arşiv numarası ile kayıtlıdır.

$$
\text { الانتظامه لايقدركه نهايه ثناء بلا غايه اول خالق سموات بديع النظام و صانع نيّر ات عجيب }
$$


sözleriyle başlar. Talik hatla, Türkçe, 210x150 (150x90) mm. ölçüsünde, 1 b - 3a sayfaları arasında, 25 satırlı, suyolu filigranlı kâğıda yazılmıştır.

Müellif adı olarak Gelibolulu Mahmud Çelebi kayıtlıdır. 1119 (1706) tarihinde istinsah edilmiştir. Celâleddin Suyûtî'nin kıyamet kopması ahvaline dair risalesinin tercümesidir.

دنياناو عاقبتنا خير ا وقدّرلنا فى الجنان سير ا امين يا رب العالمين تمت الرسالة بفة

سنه

sözleriyle sona erer.

\section{Risâle-i Beyân-ı Ömr-i Dünyâ (I Nüshası)}

Konya Bölge Yazma Eserler Kütüphanesi Isparta Yalvaç İlçe Halk Kütüphanesi Koleksiyonunda 32 Yalvaç 107/12 arşiv numarası ile kayıtlıdır.

$$
\text { بديع النظامه و صاله ء بيان عمر دنيا بسم ... حمد بى نهايه و ثناء بى غايه اول خالق سموات }
$$

sözleriyle başlar. Talik hatla, Türkçe, 200x125(140x90) mm. ölçüsünde, 275a - 277a sayfaları arasında, 18 satırlı, krem rengi cedid kâğıda yazılmıştır. Sırtı ve sertabı kahverengi meşin, üzeri desenli bez kaplı, mıklebli, mukavva bir cilt içindedir.

Müstensih adı olarak Ali Rıza b. Mehmed Rüşdi Yalvaci kayıtlıdır. Telif ya da istinsah tarihi belli değildir. Ancak aynı cilt içerisinde 1291(1873) tarihinde istinsah edilmiş bir eser ve 1293(1876) tarihlerinde istinsah edilmiş 2 eser vardır.

$$
\text { .... عائد اولور و الهه اعلم بالصواب على الايجاز و الاطناب وصلى الله على سيدنا }
$$

sözleriyle sona erer.

\section{Risâle-i Bekâ'-i Dünyâ (İ Nüshası)}

Manisa İl Halk Kütüphanesinde 45 Hk 1660/2 arşiv numarası ile kayıtlıdır.

$$
\text { عجيب الانتظامه .... . حمد بى حدو ثناى لا يعد اول خالق سموات بديع النّام و صانع نير ات }
$$


sözleriyle başlar. Talik hatla, Türkçe, 162x140(160x110) mm. ölçüsünde, 9a - 10b sayfaları arasında, 21 satırlı, rutubet lekeli, filigranlı krem kâğıda yazılmıştır. Çaharkuşe vişne rengi meşin, üstü ebru kâğıt kaplı, mıklebli, mukavva bir cildi vardır.

Müellif adı olarak Kemal Paşazade Şemseddîn Ahmed b. Süleymân (873-940/1468-1543) kayıtlıdır. Telif ya da istinsah tarihi belli değildir.

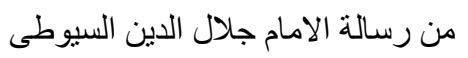

sözleriyle sona erer.

si)

Risâle fî-Hakki'd-Dünyâ ve Bekâ'ihâ ve Zevâlihâ (J Nüsha-

Kastamonu Yazma Eser Kütüphanesinde 37 Hk 1073/9 arşiv numarası ile kayıtlıdır.

$$
\text { الانتظامه لايقدركه... مهايه ثناء بى غايه اول خالق سموات بديع النظامه و صانع نيّر ات عجيب }
$$

sözleriyle başlar. Talik hatla, Türkçe, 205x145(175x125) mm. ölçüsünde, 163b - 164b sayfaları arasında, 27 satırlı, suyolu filigranlı kâğıda yazılmıştır. Mıklebli, ebrulu, mukavva, çaharkuşe meşin bir cilt içerisindedir.

Müellif adı olarak Kemâl Paşazade Şemseddîn Ahmed b. Süleymân (873-940/1468-1543) kayıtlıdır. Telif ya da istinsah tarihi belli değildir. Ancak aynı cilt içerisinde 992(1583) tarihinde istinsah edilmiş bir eser vardır.

$$
\text { و الحمد لله ربّ العالمين مولفات كمال باثنا }
$$

sözleriyle sona erer.

Farklı şahıslara izafe edilen eserin nüshalarından herhangi birisi diğerine tercih edilmemiş, metin kurulurken bütün nüshalar değerlendirmeye alınmıştır. 


\title{
METİN
}

\section{Risāle-i Aḥvāl-i Ḳıyāmet ${ }^{10}$ \\ Bismillāhirraḥmānirrahīm}

\author{
[A 141a, B 68b, C 47b, D 38a,
}

E 12a, F 1b, G 11b, H 1b, I 275a, İ 9a, J 163b] Hamd-i bī-

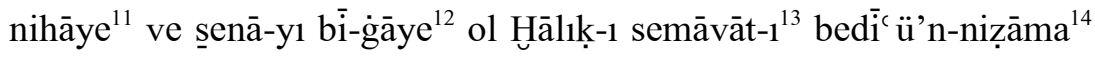
ve Șānic $-\mathrm{i}$ neyyirāt-1 'acíbü'l-intiẓāma ${ }^{15}$ lāyıḳdur $\mathrm{ki}^{16}$ cevāhir-i zevāhir-i maḥāmidāt-1 ${ }^{17}$ zaât-1 ${ }^{18}$ bì-şerìki elsine-i aḥvāl-i ${ }^{19}$ mevcūdāt-1

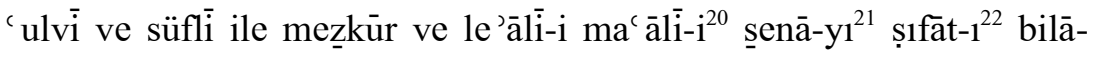

10 Başlık: Risāle-i Aḥvāl-i Ḳıāmet li-ibn-i Kemāl Paşa 'aleyhi'r-Raḥmetihi A, Fāż1l-1 Yegāne 'Allāme-i Zamāne Şeyhü'l-İ̀slām Müfti'l-Enām el-Mevlā Ebūssu' ùd el-'İmādī ibnü'ş-Şeyh Yavșiü'l-İskilībī Hażretleri'nüñ Aḥvāl-i Ḳıyāmete Müte`alliḳ Olan Risāle-i Şerífeleridür. B, Risāle-i Celāleddīn Monlā Suyūṭi C, Bismillāhirraḥmānirrahịim D, Sulțānü'l-'Ulemā fí̀'r-Rūm Merḥūm Kemāl Paşa-z̄āde'nüñ Risālesidür. E, Hāẓā er-Risāletihi fī-Beyān-1 'Ömri'dDünyā-yı Celāleddīn F, Celāleddīn Suyūtịi'nüñ Kııāmet Kopması Ahvāline Müte allik Risāle-i Şerifinüñ Tercemesidür. Gelibolu[lu] Meḥmed Çelebi Efendi itmişlerdür. Raḥimehullāh G, Celāleddīn es-Suyūțìnüñ Kıyāmet Kopması Aḥvāline Müte` allik Risāle-i Şerifinnüñ Tercemesidür. Gelibolulu Maḥmūd Çelebi Efendi İtmişlerdür. H, Hāz̄ā er- Risāle fī-Beyān-1 'Ömri'd- Dünyā li-Mevlānā Celāleddīn 'aleyhi'r-Raḥmetullāhü'l-Mu' in I, Bismillāhirraḥmānirraḥim İ, J'de başlık yok

11 bī-nihāye: bī-ḥadd B, E, İ

12 bì-gāàye: lā-yu'ādd B, E, İ; bilā-gāàye C, F, G, H

13 Hुāliḳ-i semāvāt: Hुāliḳü's-semāvāt C, F

14 bedī ü’n-niẓāma: bedī ü’n-niẓām E, G, H; bedāyī ü’n-niẓām B; bedī ü’n-neẓẓār $\mathrm{C}$

15 intizāama: intizāāa C

16 intiẓāma lāyıḳdur ki: intiẓām ḥażretine lā-yu'add B, intiẓāma ki lā-yu'add E, intiz̄āma lā-yu' add İ

17 maḥāmidāt: mahāmidāt ile B, E

18 zāt: H'de yok

19 aḥvāl: B, F, I'da yok

20 le 'ālì-i ma ālì' : vālì A, vālì-i ma ālì D, F, I, İ, J

21 senā. J'de yok 
teşrīki şifāh-1 mükevvenāt-1 mașnū āt ile menşūrdur ve șalāt-1 ${ }^{23}$ bi hadd u selām-1 ${ }^{24}$ lā-yu' add ol mefhar-i ${ }^{25}$ mefāhir-i beni ${ }^{26}$ Ādem belki dürr-i ${ }^{27}$ ferīd-i baḥr-i 'ālem ${ }^{28}$ cenābına ensebdür ki ${ }^{29}$ hadīis-i şerif-i 'irfān-bahşş ḳāmic-i zalām-1 cehl ve kelām-1 laṭif-i ma'ārif-naḳş1 lāmi' -i envār-1 'aḳl u naḳldür ve rıḍaanullāhi ve rạ̣metihỉ ${ }^{-30}$ Rabbi ālihī āl ü aṣhāb ve evlād ü aḥbābları üzerine ${ }^{31}$ olsun ki her biri necm$\mathrm{i}^{32}$ burc-1 hidāyet ve seyyāre-i nüh ${ }^{33}$ çarḩ-1 ' ināyetdür. Rıḍvānullāhi [B 69a] te ālā 'aleyhim ecma' in ve ba 'dehu ${ }^{34}$ [E 12b] ma' lüm-1 erbāb-1 ${ }^{35}$ tabāyi ${ }^{-} i^{36}$ hikmet- perver ve mefhūm-1 aṣhāb-1 ${ }^{37}$ 'uḳūl ü ma'ārifgüster ola ki şems-i āsmān-1 ' ulūm ve bedr-i eflāk-i fuhūm ve e $^{38}$ aṭābahşs-i ma ārif -i yaḳin ve rāh-nümā-y1 ${ }^{39}$ maḳāṣıd-1 müttaḳin ${ }^{40}$ a $^{c}$ ni bih $^{41}$ Celāleddīn es-Suyūtị ${ }^{\overline{4} 2}$ raḥmetullāhi te ${ }^{c} \bar{a}^{-a^{43}}$ şu semt ile ${ }^{44}$ taḳirir-i

22 șifăt: B'de yok

23 șalāt: șalavāt B, șalāt-1 șala[vā]t C, G, H

24 selām: șalāt -1 selām C, G, H

25 mefhar: fahr B

26 benì: ebi F, ibn I

27 dürr: F, I'da yok

28 baḥr-i 'ālem: baḥr-i ' ālem șallallāhu 'aleyhi ve sellem B

29 ki: B'de yok

30 raḥmetihi: raḥmetullāhi $\mathrm{C}$

31 üzerine: üzerlerine A, H, İ

32 necm: necm-i ' ulviyyet I

33 nüh: A, C, D, E, F, G, H, I, İ, J'de yok

34 Riḍvānallāhi te ālā 'aleyhim ecma 'in ve ba' dehu: A, C, D, F, I, İ, J'de yok; ba' dehu E, G, H

35 erbāb: A, B, D, E, F, G, I, I'de yok

36 țabāyi` : țıbāc B, C, G, H

37 aṣhāb: B'de yok

38 ve: B, C, D, E, F, G, H, I, I, J'de yok

39 rāh-nümā: reh-nümā B

40 müttakịin: metin B

${ }^{41}$ bih: A, B, E, I'de yok

42 es-Suyūti: A, B, D, E, F, G, H, I, İ, J'de yok

43 raḥmetullāhi te'ālā: A, C, D, F, G, J'de yok 


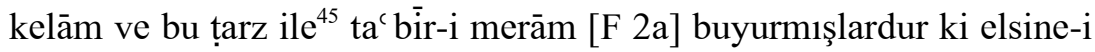
'avāmda şāyic ve şifāh-1 enāmda zāyí' dür ki $^{46}$ Hażret-i netīce-i muḳaddemāt-1 mahlūḳāt ${ }^{47}$ ve Cenāb-1 gāyet-i ${ }^{48}$ muḳaddemāt-1 mükevvenāt ${ }^{49}$ kabr-i pākinde ve merḳad-1 '1ṭ̂nākinde ${ }^{50}$ biñ yıldan ziyāde nühüfte vü nihāde olmaya. Lākin bu kelāmuñ aṣlı bāṭl ve esāsı [C 48a] 'āṭlldur. ${ }^{51}$ Belki eșaḥḥ-1 kelām ve evżaḥ-1 ${ }^{52}$ merām budur ki bu ümmet-i sa ādet-behcet ${ }^{53}$ ve bu ța 'ife-i şeref-ṣoḥbetüñ bekāâs1 ve birbiriyle ictimā ${ }^{\text {c54 }}$ ü liḳāss ${ }^{55}$ biñ yıldan ziyādedür. [I 275b] Lākin ol ${ }^{56}$ biñ y1l üzerine ${ }^{57}$ ziyāde olan evḳāt ne ḳadar vaḳtdür ${ }^{58}$ kimesneye ${ }^{59}$ ma lūm ve bir ehada mefhūm [G 12a] degüldür. Ol zā'id ${ }^{60}$ olan $^{61}$ ancak bu hadd ile maḥdūd ve bu ${ }^{62}$ (add ile $\mathrm{e}^{63} \mathrm{ma}^{\text {c }}$ dūddur ki beş yüz yıldan $\mathrm{kem}^{64}$ ü nāḳ̂ṣ ve 'aded-i mahșūṣdan bir mertebe ya merātible nāḳıṣa-i

44 semt ile: resm ile B

45 tarz ile: tavr ile A

46 zāyī` dür ki: bedāyi` dür ki A, B, D, E, F, I

47 muḳaddemāt-1 maḩlūḳāt: muḳaddemāt ve mefhar-i mevcūdāt șallallāhu 'aleyhi'ṣșalavāt ve't-tahiyyāt $\mathrm{B}$, muḳaddemāt ve mefhar-i mevcūdāt $\mathrm{E}$

48 gāyet:A, B, D, E, F, I, İ, J'de yok

49 cenāb-1 gāàet-i muḳaddemāt-1 mükevvenāt: B, E'de yok

so merḳad-1 ' 1 țr-1 nākinde: $\mathrm{B}, \mathrm{C}$ 'de yok

51 ve esās1 'āṭıldur: B’de yok; ve esāsı āṭıl A, D, F, J

52 evżaḥ: vāżı̣ B

53 behcet: himmet $\mathrm{F}$

54 ictimāe $^{-}$F, I'da yok

55 liḳāsı: iltikāsı C, G, H

56 ol: İ'de yok

57 y1l üzerine: yıldan B, E

58 ḳadar vaḳtdür: ḳadardur $\mathrm{H}$

59 kimesneye: kimseye B, E

60 zā'id: ziyāde İ

${ }^{61}$ olan: D, F, G, H, I, J'de yok

62 bu: C'de yok; ol B, E

63 'add ile: 'add ile şümārende ve $\mathrm{H}$

64 kem: F, I'da yok 
müteḥașṣıșadur ${ }^{65} \mathrm{ve}^{66}$ bu dac vānuñ şāhidi ${ }^{67}$ ve beḳā-yı dünyā yedi biñ

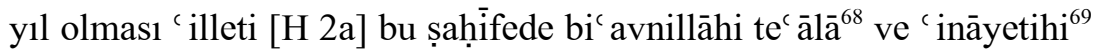
mezkūr ${ }^{70}$ ve bu varaḳla ${ }^{71}$ merḳūm u manzūur ${ }^{72}$ u masțūr ${ }^{73}$ olur. ${ }^{74}$ Evvelā bekāa-y ${ }^{75}$ [B 69b] dünyā cemí an yedi biñ yıl idügine şehādet iden şuhūd-i ehādīs $-i \quad$ Resūl-i $^{76} \quad$ ekrem $^{77}$ șallallāhu te āală ${ }^{78 c}$ aleyhi ve

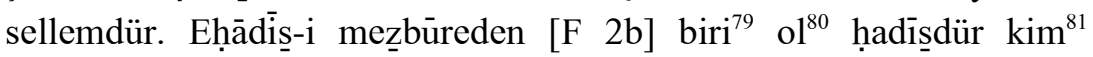

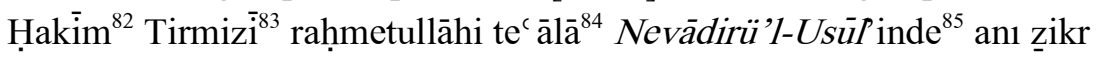
itmişdür bu ${ }^{86}$ c ibāretle ${ }^{87}$ :

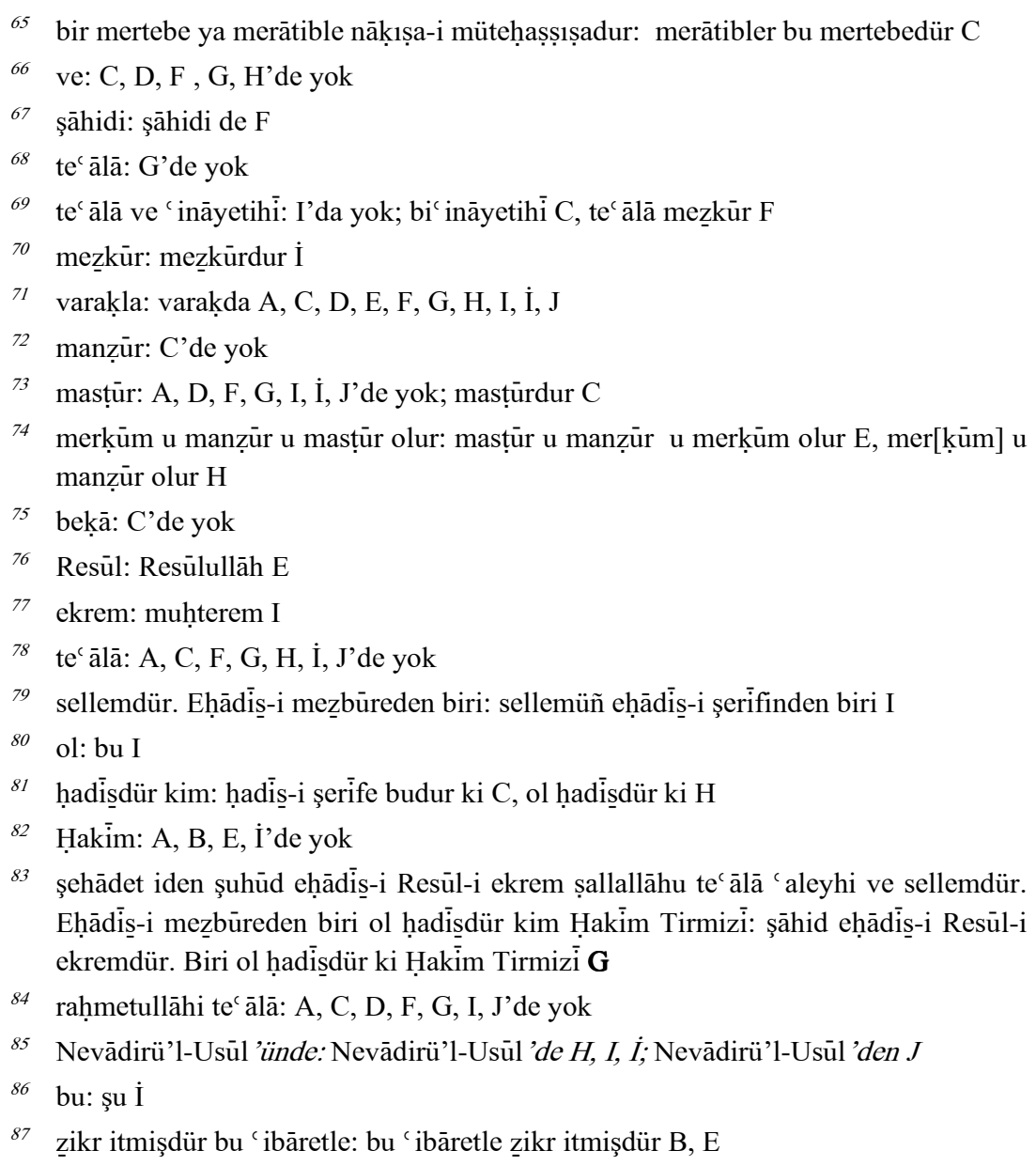




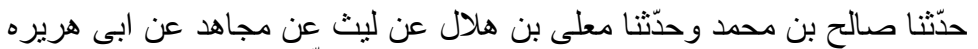

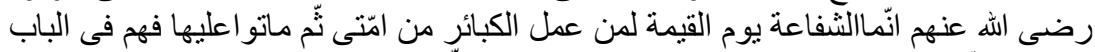

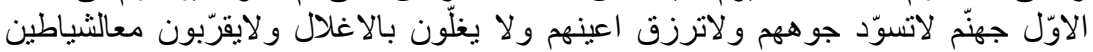

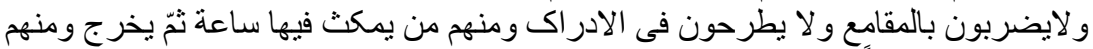

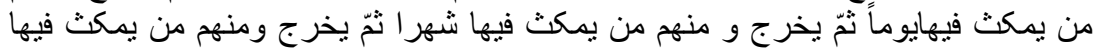

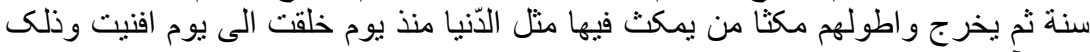
سبعة آلاف سنته

[A 141b, C 48b, D 38b, E 13a, İ 9b] Ya' nï "Benüm ${ }^{89}$ şefăc atüm ḳıyāmet güninde ümmetümden kebā'ir işleyüb bilā-tevbe ${ }^{90}$ ölenleredür. ${ }^{91} \mathrm{Ol}$ tạ 'ife țabaḳāt-1 ${ }^{92}$ cehennemden țabaḳāt-1 ūlāda ${ }^{93}$ sākin olurlar $^{94}$. Anlaruñ yüzleri ${ }^{95}$ siyāh ve gözleri gök olmaz ve ${ }^{96}$ anlaruñ boyunlarına zencīi ${ }^{97}$ urulmaz $^{98}$ ve $\operatorname{anlar}^{99}[\mathrm{~B}$ 70a $]$ şeyātịn ile ${ }^{100}$ ḳoşulmaz $^{101}$ ve dahi ḳamcılarla ḍarb olunmazlar ${ }^{102}$ ve sā'ir țabaḳāt-1 cehenneme mațū ${ }^{103}$ olmazlar. Ol țā ifeden ${ }^{104}$ ba $^{c}$ żis1 ${ }^{105}$ cehennemde $^{106}$ ancak bir sā̄a at eglenüp ${ }^{107}$ andan șoñra benüm şefāa atüm ${ }^{108}$ sebe-

88 ya' niं: terceme $\mathrm{C}, \mathrm{G}, \mathrm{H}$

89 benüm: B'de yok

90 bilā-tevbe: bilā-tevbe mușirren fevt C, G, H; bilā-tevbe fevt D, F, J

91 ölenleredür: ölenlere A

92 țabaḳāt: C'de yok

93 țabaḳāt-1 ūlāda: ednā țabaḳada C

94 olurlar: olur C, G, H

95 yüzleri: G'de yok; yüzi A, C, D, F, J

96 ve: A'da yok

97 zencirir: zenciirler A, D, E, G, İ, J

98 urulmaz: urmazlar B, D, F, İ

99 anlar: anlara B

100 ile: B'de yok

101 ḳoşulmaz: ḳoşmazlar B, ḳoşulmazlar C, D, E, G, H, İ, J

102 darb olunmazlar: maḍūu olmazlar A, D, E, F, G, H, İ, J; urulmazlar C

103 mațrūh: țarh A, B, C, D, E, F, G, İ, J

104 yüzi siyāh ve gözleri gök olmaz ve anlaruñ boyunlarına zencīir urmazlar ve anlar şeyātīn ile ḳoşulmaz ve dahi ḳamcılarla ḍarb olunmazlar ve sā'ir țabaḳāt-1 cehenneme matrūh olmazlar: F, I'da yok

$105 \mathrm{Ol}$ țā'ifeden ba' żisı: anlaruñ ba' ż1sı F, I

106 cehennemde: sa ${ }^{`}$ ïrde $\mathrm{C}$ 
biyle $^{109}$ çıkarlar ${ }^{110}$ ve ba żı āher ancak bir gün ${ }^{111}$ eglenüp benüm şefā' atümle çıkarlar ${ }^{112}$ ve ba ${ }^{c}$ ż āher ${ }^{113}$ [F 3a] bir ay eglenüp ${ }^{114}$ ve ba ${ }^{c} \dot{z} 1$ āher bir y1l eglenüp ${ }^{115}$ be-ġāyet ${ }^{116}$ çok eglenen ${ }^{117}$ dünyā 'ömri ḳadar cehennemde $^{118}$ eglenüp $^{119}$ ba $^{c}$ dehu ${ }^{120}$ benüm ${ }^{121}$ şefā' atüm sebebiyle ${ }^{122}$ çıḳarlar. ${ }^{123}$ [I 276a] Dünyānuñ 'ömri kadar ${ }^{124}$ dimekden murād ${ }^{125}$ àdem $^{126}$ yaradıldığı zamāndan fāni ${ }^{127}$ oldug̀ı zamāna dekdür ${ }^{128}$. Ol

107 eglenüp: I'de yok; eglenür B, C, D, E, G

108 andan șoñra benüm şefā' atüm: İ'de yok

109 sebebiyle: I'de yok; ile F, G, I

110 çıḳarlar: I'de yok; çıḳar C

111 ve ba'żı āherer ancak bir gün: A, B, E, F, I'da yok; ve ba' żısı dahi ancaḳ bir gün G, ve ba' $̇$ żsı bir gün İ

112 eglenüp benüm şefā' atümle çıkarlar: A, B, C, E, F, I, İ'de yok; eglenüp șoñra benüm şefācatümle çıkarlar $\mathrm{G}, \mathrm{H}$

113 ba` ̇̇ı āhher: ba` żısı dahi G, ba`żısı İ

114 eglenüp: C, İ'de yok, eğlenür $\mathrm{H}$

115 ve ba`żı āher bir yıl eglenüp: ba'dehu benüm şefā‘ atüm sebebiyle çıḳarlar ve ba $^{`} \dot{z} 1$ āher bir yıl eglenür B, ve ba' żı āher bir yıl eglenür C, ve ba' żısı dahi bir yıl eglenür G, ve ba ${ }^{`} \dot{z} 1$ āher altı ay eglenür ve $b a^{`} \dot{z} 1$ āherer bir yıl eglenür $\mathbf{H}$, ve ba żısı bir y1l I

116 be-ḡāyet: gāayetle B, D, İ, J; ḳatı C, ġāyet E, F, G, H, I

117 eglenen: eglenüp çıḳan $\mathrm{G}$

118 cehennemde: C, I'de yok

119 eglenüb: eglenür B, C, G, H

120 ba' dehu: B'de yok; șoñra İ

121 benüm: C, G, H'de yok

122 ba' dehu benüm şefā'atüm sebebiyle: öyle F, I

123 ve ba` żı āher ancaḳ bir gün eglenüb benüm şefā' atümle çıḳarlar ve ba`ż āher bir ay eglenüb ve ba`ż̇ āher bir yıl eglenüb beḡāyet çok eglenen dünyā 'ömri ḳadar cehennemde eglenüb ba' dehu benüm şefā' atüm sebebiyle çıkarlar. : E'de yok

124 kadar: B, C, D, E, F, G, H, I, İ, J'de yok

125 murād: murādum B, E, F, I

126 ādem: C, F, G, H, I'da yok; Ādem 'aleyhi's-selām B

127 fānì: ifnā C

128 dekdür: dekdür dimekdür $\mathrm{C}, \mathrm{H}$ 
zamān ${ }^{129}$ yedi biñ yıldır." Bu ma' nāda ${ }^{130}$ pes cemiَ' -i müddet-i beḳā-y1 dünyā ve mevsim-i ibtidā'-i 'uḳbā yedi biñ yıldır. ${ }^{131}$ [J 164a] Bu ma' nāda ${ }^{132}$ kelām-1 Resūl-i ekrem ve hadīs-i efḍal-i Resūl-i mu' aẓẓam șallallāhu te ${ }^{c} \bar{a}^{-1} \bar{a}^{133}$ caleyhi ve sellemdür ${ }^{134}$. Ammā ${ }^{-135}$ bu ümmet-i pürḥaşmet ve bu țā 'ife-i bā - izzetüñ beḳās1 ${ }^{136}$ biñ ${ }^{137}$ yıldan ziyāde idügine hüccet ve bu da'vāya şāhid-i șahịhh-i bī-c illet oldur ki aḩbār-1 Resūl-i ekrem șallallāhu te ālā ${ }^{-138}$ c aleyhi ve sellemde vāriddür ki Deccāl-i [C 49a] bed-fi āl re's-i mi'ede hurūc ve 'ālem-i ḳayddan ${ }^{139}$ 1ṭlāḳa 'urūc ider. 'Aḳabince Hażret-i ' '̇̃ā ' aleyhi's-selām ${ }^{140}$ semādan arża nāzil olub Deccāl' ${ }^{141}$ katl idüp yiryüzinde ḳık yıl sākin ve bu müddet dār-1 fenāda [E 13b, H 2b] mütemekkin olur. Ba' dehu şems-i 'ālem-tāb cānib-i garbdan ${ }^{142}$ tulü $\bar{u}^{c}$ ider. Ba' dehu yüz yigirmi [B 70b] y1l halāyık ma ${ }^{\text {ișet itseler }}{ }^{143}$ gerekdür $^{144}$ ve biri biriyle mukārenet ve șoḥbet ${ }^{145}$ it-

\footnotetext{
129 zamān: zamāndan $\mathrm{B}$, zamāndan berü $\mathrm{A}, \mathrm{E}$

130 bu ma' nāda: C, D, F, G, H, I, J'de yok

131 y1ldir: F'de yok

132 pes cemī -i müddet-i beḳā-yı dünyā ve mevsim-i ibtidā'-i 'uḳbā yedi biñ yıldır. Bu ma' nāda: B, E, İ'de yok

133 te ālā: B, I, İ, J'de yok

134 sellemdür: sellem B

135 șallallāhu te ālā 'aleyhi ve sellemdür. Ammā: çoḳdur. Ammā C, G, H

136 beḳāsı: ibḳāsı C

137 biñ: yedi biñ $\mathrm{B}, \mathrm{H}$

138 te' ālā: A, B, C, D, F, G, H, I, İ, J'de yok

139 kayddan: G'de yok

140 'aleyhi’s-selām: ‘ale'n-nebiyyinā ve 'aleyhi'ṣ-șalavātü'l-mevlā B, E; ‘ale’nnebiyyinā ve 'aleyhi's-selām C, șallallāhu 'ale'n-nebiyyinā ve 'aleyhi's-selām D,İ, J; șallallāhu 'ale'n-nebiyyinā ve 'aleyh F, șallallāhu 'aleyhi ve sellem G, șalavātullāhi ' ale'n-nebiyyinā ve 'aleyh H

141 Deccāl: Deccāl-i bed-fi' āl İ

142 garbdan: magribden C, D, F, G, J

143 itseler: itse A

144 itseler gerekdür: B'de yok

145 șoḥbet: șoḥbetler G
} 
seler gerekdür. ${ }^{146}$ Andan șoñra ${ }^{147}$ nefhạa-i [F 3b] ūlā çalınup ḳırḳ yıl dahi ${ }^{148}$ nefhateyn ortası olsa ${ }^{149}$ gerekdür. Pes imdi ḳıām-1 ${ }^{150}$ ḳıāmet ve inbi ās̄-1 sā' at olınca olacak emrler ancaḳ iki yüz senede mümkin olur. Biñ y $1^{151}$ tamām olmag̉a ḩod ${ }^{152}$ yüz ${ }^{153} \mathrm{iki}^{154}$ sene ḳalmışdur. Öyle olsa $^{155}$ tamām-1 elfde ${ }^{156}$ [D 39a] ḳıyām-1 ${ }^{157}$ kıyāmet gayr-i mümkindür. Pes imdi ${ }^{158}$ biñ y1l üzerine ziyāde emr zāāir-i münīrdür. ${ }^{159}$ Ammā Deccāl re's-i mi 'ede hurūc idüp ${ }^{160}$ ba' dehu Hażret-i ${ }^{161}$ (İंsā 'aleyhi'sselām ${ }^{162}$ yiryüzine nāzil olup Deccāl'i ḳatl idüp yine ${ }^{163}$ yiryüzinde tamām ${ }^{164}$ ḳırk y $1^{165}$ eglendügine ${ }^{166}$ şehādet iden ${ }^{167}$ şāhid ve bu ${ }^{168}$ bisāṭ-1

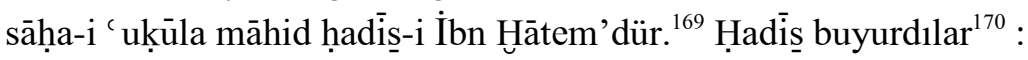

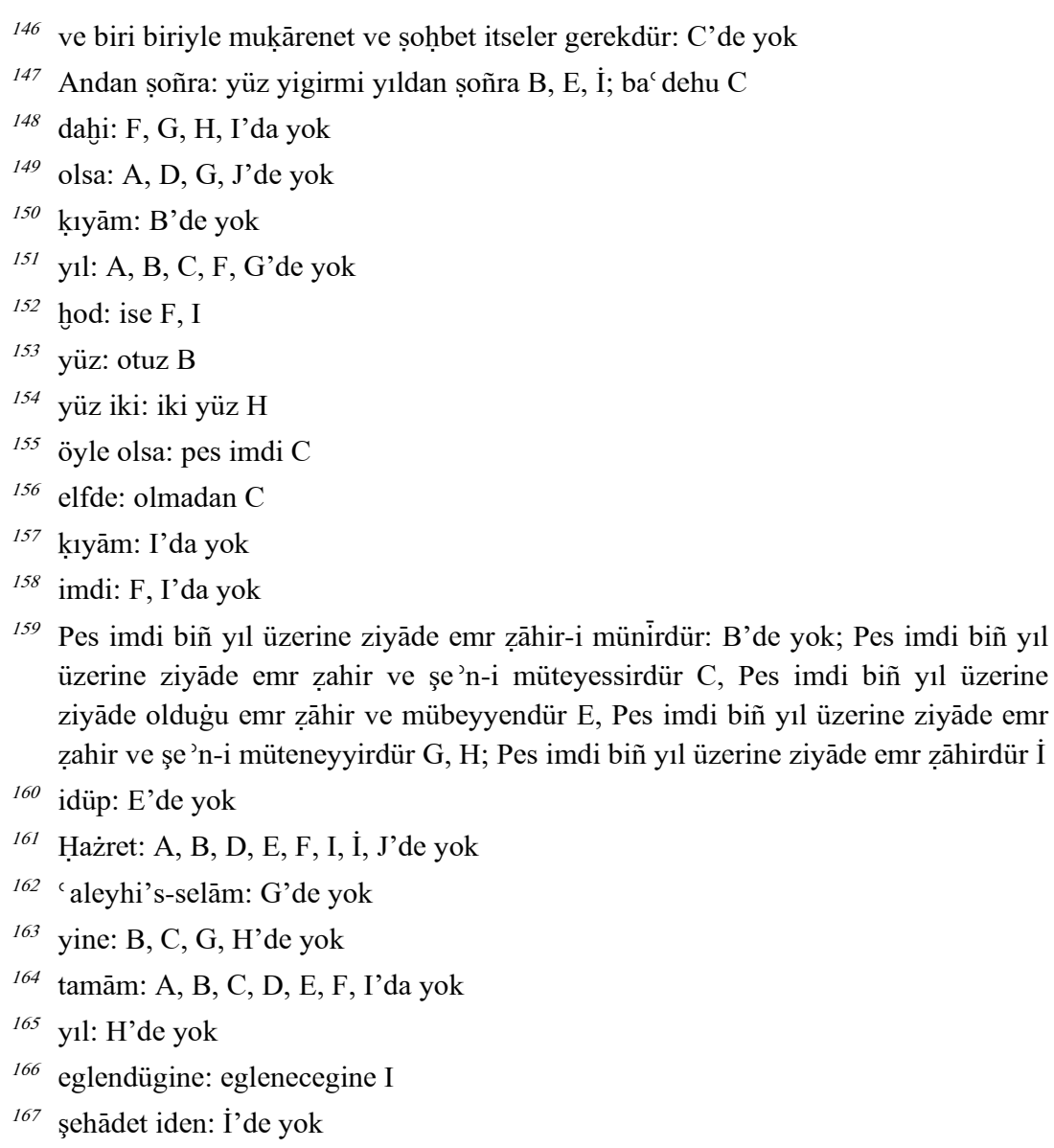




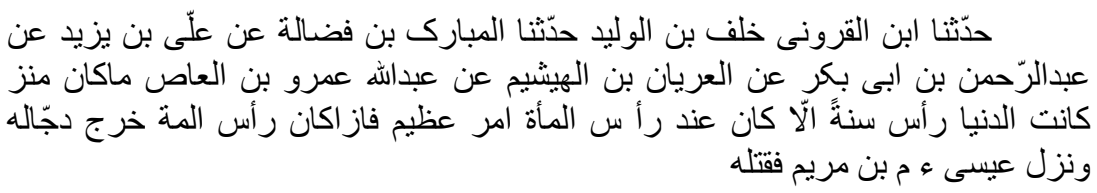

[A 142a, C 49b, I 276b, İ 10a] Ya'nīi dünyā mevcūd olaldan ${ }^{172}$ berü hịç ${ }^{173}$ yüz y1 ${ }^{174}$ baş1 yoḳdur ki ${ }^{175}$ anda bir emr-i ' azịim olmaya. [F4a] Bu üslūb üzerine ${ }^{176}$ kaçan re's-i mi'e olsa Deccāl hurūc

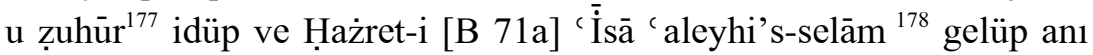

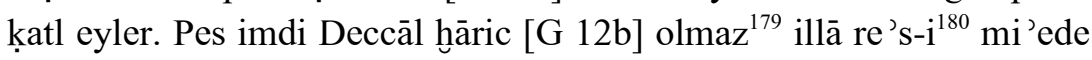
hāric olur. Ba' dehu Ṭaberānī, ‘ Abdullāh ibn Selām'dan bu hadīis-i şerifi rivāyet ider ki hadi ${ }^{18}{ }^{18}$

$$
\text { 182ilh. قال يمكث النّاس بعد الدجال اربعين سنة }
$$

168 bu: A, B, E, F, G'de yok

169 Hูātem'dür: Hูālid'dür ki B

170 Ḥadis buyurdılar: buyurur B, E, I; buyurdılar ki C; buyurdılar D, F, G, H, İ; buyurdılar hadis $\mathrm{J}$

171 ya' nì: terceme ya' ni $\mathrm{C}, \mathrm{G}, \mathrm{H}$

172 mevcūd olaldan: vücūd bulaldan B

173 hiç̧: I'de yok

174 yıl: C, G, H'de yok

175 yoḳdur ki: yoḳdur D

176 üzerine: üzre B

177 ve zuhūr: B, C, D, E, F, G, H, İ, J'de yok

178 'aleyhi's-selām: C, D, E, G, H, J'de yok

179 hāric olmaz: hurūc itmez F, I

180 re's: E'de yok

${ }^{181}$ Ba'dehu Ṭaberānī 'Abdullah ibn Selām'dan bu hadīș-i şeríifi rivāyet ider ki: hadīs Resūlullāh șallallāhu 'aleyhi ve sellem buyurur A, hadīis Resūl-i ekrem șallallāhu 'aleyhi ve sellem der ki B, hadiș-i Resūl-i ekrem șallallāhu te'ālā 'aleyhi ve sellem D, hadīis-i Resūl-i ekrem șallallāhu 'aleyhi ve sellem E,J; hadīș-i Resūl-i ekrem F, I; ḥadīs-i Resūlullāh șallallāhu 'aleyhi ve sellem der İ; hadiṣ̂i Resūl șallallāhu 'aleyhi ve sellem J

182 ilh. :A, B, C, D, E, F, I, J'de yok 
[E 14a] Ya nī $^{183}$ nās Deccāl'den șoñra ḳırḳ y1l yiryüzinde ${ }^{184}$ mütemekkin olurlarr ${ }^{185}$. Ammā hurşìid-i 'ālem-tāb cānib-i mag̉ribden țulū` itdükden șoñra halḳ-1 'ālem ve efrād-1 beni Ādem yüz yigirmi y11 ${ }^{186}$ yiryüzinde ${ }^{187}$ ber-ḳarār ${ }^{188}$ ve bu ḳadar zamān geşt ü güz̄ār

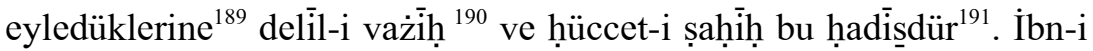

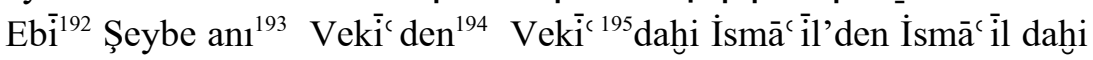
'Abdü's-selām'dan' ${ }^{196}$ raḍiyallāhu 'anhüm ${ }^{197}$ rivāyet ider. ${ }^{198}$ Resūl-i ekrem șallalāhu te ālā'199 'aleyhi ve sellem ḥażretleri ${ }^{200}$ buyurmışlardur ${ }^{201}$ ki hadi $\bar{i}^{202}$ :

$$
\text { يمكث النّاس بعد طلوع الثمس مغربها عثرين و مائة سنة }
$$

\footnotetext{
183 ya' nì: terceme ya' ni C, G, H

184 yiryüzünde: C'de yok

185 olurlar: olur C

186 y1: H'de yok

187 yiryüzinde: B'de yok

188 ber-ḳarār: ḳarār C

189 eyledüklerine: itdüklerine $\mathrm{C}, \mathrm{F}, \mathrm{G}, \mathrm{H}$

190 vażị̣: vāżı̣ A,C, D, E, F, G, H, I, İ, J

191 bu hadīisdür: hadīisdür ki C

192 Ebì: B, C, E, I'de yok

193 anı: B, I'da yok; ebi F, ibn G

${ }^{194}$ Veki' den : E'de yok, Vekil'den C

195 Veki' : F'de yok, Vekil C, ol I

196 'Abdüsselām'dan: Nebī ' aleyhi's-selām'dan C

197 raḍiyallāhu 'anhüm: A, C, D, F, G, H, I, J'de yok

${ }_{198}$ rivāyet ider: B, E'de yok

199 te ālā: B, C, G, H, I, İ, J'de yok

200 ḥażretleri: A, B, C, D, E, G, H, İ, J'de yok

201 'Abdüsselām'dan radiyallāhu 'anhüm rivāyet ider. Resūl-i ekrem șallalāhu te'ālā 'aleyhi ve sellem hạżretleri buyurmışlardur: Ḥażret-i peyġāmber 'aleyhi'sselāmdan rivāyet ider ki İ

202 hadīis: B, C, D, E, F, I, I'de yok
} 
$Y^{c}{ }^{c} \bar{i}^{203}$ güneş cānib-i ${ }^{204}$ mağribden țulū' itdükden șoñra halk dār-1 fenāda yüz yigirmi y1l sākin ve bisāṭ-1 hākde bu müddet ${ }^{205}$ mütemekkin olurlar. ${ }^{206}$ Ammā beyne'n- nefhateyn ${ }^{207}$ kırk yı1 ${ }^{208}$ olmasına [F 4b] hüccet ve bu ${ }^{209}$ müddec àya 'illet [C 50a] Resūl-i ekrem ${ }^{210}$ șallallāhu te ālā ${ }^{-211}$ 'aleyhi ve sellem hażretleri ${ }^{212}$ buyurmışlardur. ${ }^{213}$ Hadis ${ }^{214}$ :

$$
\text { بين النفختين اربعين عامً وقال بين النفختين اربعون سنة } 215
$$

[H 3a] Eger bu gūne su 'āl ve bu vech ile ${ }^{216}$ kịil ü kāl olunursa ki Fahr-i 'ālem seyyid-i veled-i ādem șallallāhu [B 71b] 'aleyhi ve sellem $^{217}$ şöyle buyurmışlardur. Hadi $\bar{s}^{218}$ :

$$
\text { الدنيا سبعة ايّّم كلّ يوم الف سنة و بعث فى آخر ها }
$$

[I 277a, J 164b] Eyle olsa müddet-i beḳā-y1 ümmet biñ y11 ${ }^{219}$ üzerine ziyāde ${ }^{220}$ olmaḳ $^{221}$ iḥtimāli ${ }^{222}$ emr-i muhāldür ${ }^{223}$ ve maḥżā ḳil ü

203 ya'ni: terceme ya'ni C, G, H

204 cānib: F, I'da yok

205 bu müddet: G, H'de yok; bu ḳadar müddet F, I

206 olurlar: olur D

207 beyne'n- nefhateyn: bā-beyn-i nefhateyn A, beyn-i nefhateyn D, E, F; mābeyne'n- nefhateyn $\mathrm{G}, \mathrm{H}$

208 y1l: H'de yok

209 bu: A, C, D, E, F, G'de yok

210 Resūl-i ekrem: Hażret-i Resūlullāh

211 te ālā: B, I'de yok

212 ḥażretleri: A, B, C, D, E, G, I'da yok

213 buyurmışlardur: E'de yok

${ }^{214}$ Resūl-i ekrem șallallāhu te ālā ' aleyhi ve sellem hażretleri buyurmışlardur.Hadiș: kāle Resūlullāh șallallāhu ' aleyhi ve sellem C, G, H; hadịṣ-i Resūl 'aleyhi'ṣ-ṣalātü ve's-selām D, J

2152 بين النفختين اربعين عائ وقال بين النفختين اربعون سنته : G’de yok

216 bu vech ile: B, E'de yok; bu gūne A, D, G, I, J

217 șallallāhu 'aleyhi ve sellem: A, D, E, F, G, I, I'de yok

${ }^{218}$ Eger bu gūne su'āl ve bu vech ile ḳil ü kạa olunursa ki Fahrr-1 'ālem Seyyid-i veled-i ādem șallallāhu 'aleyhi ve sellem şöyle buyurmışlardur. Ḥadiṣ: G'de yok 219 y1l: tamām İ 
kāldür. Cevābi ${ }^{224}$ budur ki mu' zạm-1 mesā'il-i ${ }^{225}$ dīn ve cumhūr-1 umūr-1 yakịin ${ }^{226}$ biñdedür dimekdür. Tā ki ol hadīse muvāfiḳ ola ve yine ${ }^{227}$ Resūl-i ekrem [D 39b] șallallāhu te ālấa ${ }^{-228}$ 'aleyhi ve sellem ḥażretleri ${ }^{229}$ buyurmışlardur ki ḥadi $\underline{1}^{230}$ :

$$
\text { بعثت فى آخر الف السادسة }
$$

Ya ni bir āher hadis elf-i sādisde $b a^{c} \underline{s}$ olundum." Ehạāisis-i eşrāța dahi ${ }^{232}$ muvāfiḳ ${ }^{233}$ olsun içün bu ma'nāya haml ${ }^{234}$ lāzib ü lāzım ${ }^{235}$ ve emr-i żarūrī [vü] mühimdür. Aḥmed bin Hanbel raḍiyallāhu ' anh ${ }^{236}$ şöyle buyurdu ki

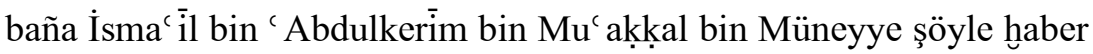
virdi ki in $^{237}$ baña $a^{238}$ ' Abdü’ș-ṣamed şöyle ${ }^{239}$ bildürdi ki [F 5a] Taḥkị bị bin Vehbe'den işitdüm ki ${ }^{240}$ [I 10b] Resūl-i ekrem ${ }^{241}$ 'aleyhi'sselāmdan ${ }^{242}$ şöyle ${ }^{243}$ rivāyet itdi ki ${ }^{244}$ buyurmışlar $^{245}$ hadis $^{246}$ :

220 ziyāde: A, B, D, E, F, İ'de yok

221 üzerine ziyāde olmaḳ: tamām olmaḳ B, E

222 ị̣timāli: A, B, C, D, E, F, I, İ, J'de yok

223 muhāldür: muhāa B, F, H, I

224 cevābı: A, B, D, E, F, G, I'da cevāb

225 mesā'il: mes 'ele C, G, H

226 cumhūr-1 umūr: umūr-1 cumhūr $\mathrm{F}$

227 ve yine: A, C, D, E, F, G, H, I, İ, J'de yok

228 te ālā: B, C, F, G, H, I, İ, J'de yok

229 hażretleri: A, B, C, D, E, G, H, İ, J'de yok

230 hadisis: B, C, D, E, F, G, H, I, I'de yok

231 bir āhir hadīs

232 dahi: B, F'de yok

233 muvāfik: muțābıḳ C, G, H

234 haml: H'de yok

235 Lāzib ü lāzım: lāzım ü lāzib B, C, D, E, F, G, H, İ, J

236 raḍiyallāhu 'anh: A, C, D, F, G, H, I, İ, J'de yok; raḍiyallāhu te ālā ‘ anh E

237 haber virdi ki: hyaber virdiler ki B, E; rivāyet itdi ki H, ahbār eyledi ki İ

238 baña: A, D, E, G'de yok

239 şöyle: A, B, E, I' de yok

240 baña 'Abdü'ṣ-șamed şöyle bildürdi ki Taḥkịị̣ bin Vehbe'den işitdüm ki: H'de yok 
TÜBAR-XXXVI-/2014-Güz / Kemalpaşazade: Ahvâl-i Kıyâmet

منها ماكان من الملوك و خلانبياً من الدّنيا خمسة آلاف سنة وستّمأة سنة لانى لاعرف كلّ زمان

[A 142b] Ya'nī "Bu zamānda ki ba's olundum ${ }^{247}$ [C 50b] dünyādan beş biñ altı yüz sene mürūr itmişdür. $\mathrm{Ol}$ zamāndan ${ }^{248}$ her cüz'de mülūk u enbiyādan kim gelmişdür [B 72a] ben bilürüm.” diyü

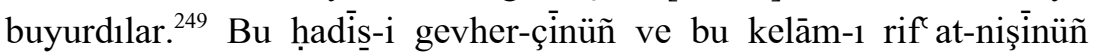
mefhūmı aña delālet ider ki bu ümmetüñ bekās $1^{250}$ biñ y11 ${ }^{251}$ üzerine dört yüz yı1 ${ }^{252}$ miḳdārı ' add ile zā 'id ve bu hadīisden erbāb-1 ' uḳūla bu ma' nā ' $\bar{a}$ 'id olur.

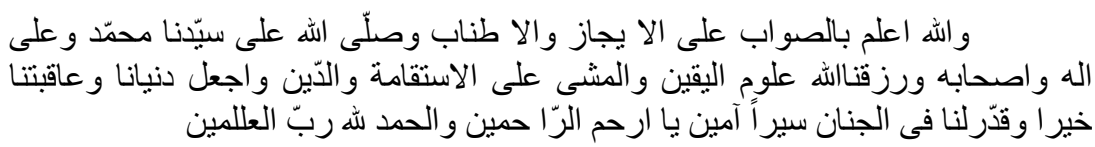

Li- ibn-i Kemāl ‘ aleyhi raḥmetihi’l- Müte` āl ${ }^{253}$

241 Resūl-i ekrem: H'de yok, Resūlullāh'dan C, Resūlullāh I, Resūl 'aleyhi'sselāmdan İ, Resūl'dan 'aleyhi's-salātü ve's-selām J

242 'aleyhi's-selāmdan: C, G, H'de yok; șallallāhu 'aleyhi ve sellemden B, I

243 şöyle: A, B, D, E, F, G, H, I, I'de yok

244 Resūl-i ekrem 'aleyhi's-selāmdan şöyle rivāyet itdi ki: Resūl'den 'aleyhi'ṣ-ṣalātu ve's-selāmdan D, F; Resūl-i ekrem șallallāhu te'ālā 'aleyhi ve sellemden rivāyet itdi ki E, Resūl șallallāhu 'aleyhi sellemden şöyle rivāyet itdi ki G

245 buyurmışlar: A, C, D, F, G, H, I, İ, J'de yok

246 hadīis: B, I, I'de yok

247 ki ba's olundum: C, G, H'de yok

248 zamāndan: zamān B, zamānda D, E, F, H

249 buyurdılar: buyurmışlar B, E

250 beḳāsı: ibkāāsı C

251 y1l: C, G'de yok

252 yıl: A, C, D, G, H, J'de yok

253 Li- ibn-i Kemāl 'aleyhi raḥmetihi'l- Müte`āl: A, B, C, D, F, G, H, I, İ, J'de yok. D'de şöyle bir istinsah kaydı vardır: Mü'ellefăt Kemāl Paşa-zāde temmet Seyyid Meḥmed 29 Cemāziyü'l-ahir sene 1203, H'de şöyle bir istinsah kaydı vardır: temmetü'r-risāletü'ş-şerife sene 1119, İ'de şöyle bir istinsah kaydı vardır:

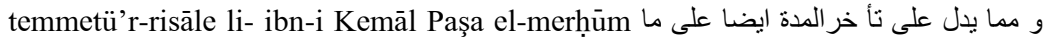

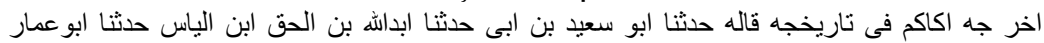

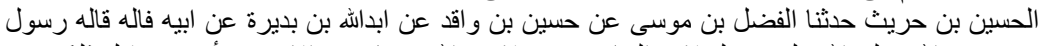

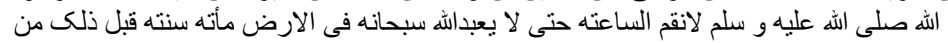




\section{KAYNAKÇA}

ALTUNTAŞ, Süleyman (2007), Kıyamet Alametleri (On Alameti Bir Arada Zikreden Rivayetlerin Tahlili), Yüksek Lisans Tezi, Ankara Üniversitesi Sosyal Bilimler Enstitüsü, Ankara.

BAŞ, Eyüp (2005), "Binyılcılık ve Osmanlı Toplumunda Hicrî Milenyum Kıyamet Beklentisi ile İlgili Bazı Veriler", Dinî Araştırmalar, C. 7, S. 21, s.163-177.

BİLMEN, Ömer Nasuhi (1973), Büyük Tefsir Tarihi (Tabakatü'l-Müfessirîn), Bilmen Yayınevi, İstanbul.

İSEN, Mustafa (1998), Sehî Bey Tezkiresi - Heşt Behişt, Akçağ Yayınları, Ankara.

İSEN, Mustafa (1994), Künhü'l-Ahbâr'ın Tezkire Kısmı, Atatürk Kültür Merkezi Yayınları, Ankara.

KALKAN, Ahmet (2012), “Kur'ân'ın Kıyamet İnancı İle Genel Kabul Gören Anlayışta Kıyamet", İktibas, S. 436, s. 25-33.

MALKOÇ, Bülent (2010), Klyamet Alametleri ve Gelecek Haberleri Konusunda Hadislerle Kitabı Mukaddes'in Karşılaştırılması, Yüksek Lisans Tezi, Erciyes Üniversitesi Sosyal Bilimler Enstitüsü, Kayseri.

PARMAKSIZOĞLU, İsmet (1977), "Kemâl Paşa-zâde", İslâm Ansiklopedisi, C. VI, Millî Eğitim Bakanlığı Yayınları, İstanbul, s. 561-566.

SARAÇ, M. Ali Yekta (1999), Şeyhülislam Kemalpaşazade, Şûle Yayınları, İstanbul.

TOPALOĞLU, Bekir (2002), "Kıyamet", İslâm Ansiklopedisi, C.25, Türkiye Diyanet Vakfı Yayını, Ankara, s. 516-522.

\section{Yazma Eserler}

Anonim, Risâle fî Ahvâli'l-Klyâme (yz), Ankara Millî Kütüphane Yazmalar Koleksiyonu, Nu. 06 Mil Yz A 5693/7, 38a-39b.

Anonim, Risâle-i Beyân-ı Ömr-i Dünyâ (yz), Ankara Milli Kütüphane Yazmalar Koleksiyonu, Nu. 06 Mil Yz A 5401/2, 47b-50b.

risāletü'l-imām Celāleddīn Suyūți, J'de şöyle bir istinsah kaydı vardır: Mü 'ellefāt1 Kemāl Paşa 
Anonim, Risâle-i Beyân-ı Ömr-i Dünyâ (yz), Konya Bölge Yazma Eserler Kütüphanesi Isparta Yalvaç İlçe Halk Kütüphanesi Koleksiyonu, Nu. 32 Yalvaç 107/12, 275a-277a.

Ebussu 'ûd Muhammed b. Muhammed el-İmâdî (yz) Ahvâl-i Kıyâmet, Kayseri Raşit Efendi Eski Eserler Kütüphanesi, Nu. Râşid Efendi 196/9, $68 \mathrm{~b}-72 \mathrm{a}$.

Celâleddin (yz), Risâle fì-Beyâni Ömri'd-Dünyâ, Ankara Milli Kütüphane Adnan Ötüken İl Halk Kütüphanesi Koleksiyonu, Nu. 06 H 4328/1, $1 b-5 b$.

Gelibolulu Mahmud Çelebi (yz), Terceme-i Risâle fì Ahvâli'l-Kıyâme, Çorum Hasan Paşa İl Halk Kütüphanesi, Nu. 19 Hk 798/4, 1b-3a.

Gelibolulu Mehmed Çelebi (yz), Terceme-i Ahvâl-i Klyâmet, Ankara Millî Kütüphane Yazmalar Koleksiyonu, Nu. 06 Mil Yz A 1941/2, 11b-12b.

Kemal Paşazade (yz), Risâle-i Ahvâl-i Klyâmet, Millet Kütüphanesi Ali Emîrî Koleksiyonu, Nu. 34 Ae Manzum 573/2, 141a-142b.

Kemal Paşazade (yz), Risâle-i Bekâ-i Dünyâ, Manisa İl Halk Kütüphanesi, Nu. 45 Hk 1660/2, 9a-10b.

Kemal Paşazade (yz), Risâle fî-Hakki'd-Dünyâ ve Bekâ'ihâ ve Zevâlihâ, Kastamonu Yazma Eser Kütüphanesi, Nu. 37 Hk 1073/9, 163b-164b.

Kemal Paşazade (yz), Risâle fi-Müddeti Hayâti'd-Dünyâ ve Eşrâti's-Sâ'a(t), Millet Kütüphanesi Ali Emiri Koleksiyonu, Nu. 3. 